\title{
Service Life Extension Program for Aircraft Structures
}

\author{
Stevan Maksimović ${ }^{1)}$ \\ Zoran Vasić ${ }^{1)}$ \\ Radoljub Došić ${ }^{2)}$
}

\begin{abstract}
Performance of aircraft in general, its systems and airframe materials, can be significantly reduced by environmental conditions in which the aircraft operates during the service life. Material performance of steel and aluminum alloys can be greatly degraded because of the environmental conditions (temperature, humidity, UV radiation, pollutants, etc.), which severely affect the integrity and safety of aircraft structure. Apart from the other severe environmental conditions, the effect of the corrosion on structural integrity is a critical issue for damage tolerance design and analysis and needs to be carefully investigated. The corrosion and corrosion fatigue failure process of an aircraft structure are directly concerned with many factors, such as load, material characteristics, and corrosive environment and so on. Attention in this paper is focused on the application of the Nondestructive Inspection (NDI) methods in the process of extension of service life of aircraft structures. The NDI methods were used as a part of service life extension program for the extension of the operation life of the G-4 Super Galeb aircraft structures that have been in service in air force for more than 25 years. The computation and experimental NDI methods and practice steps that diminish the negative effects of corrosion process were shown in this paper. Special attention in this paper is focused to the use of the NDI methods. These steps enable to extend the service life of aircraft structures beyond its designed service life with the accurate prediction of the further service reliability
\end{abstract}

Key words: aircraft, aircraft structure, fuselage, corrosion, corrosion fatigue, nondestructive inspection (NDI), service life testing, service life assessment.

\section{Introduction}

$\mathrm{T}$ ODAY many aging aircraft in air forces of many world's countries have been in service beyond their airframe nominal designed service life [1-4]. The budget restrictions for the renewal of the military technical arsenal caused such a situation. Nominally, designed service life of a typical military jet airframe structure is defined for duration from 20 up to 30 , and even more, years. The service life extension programs today are usually undertaken for a modern military aircraft due to a high cost of an airframe structure and limits of the military budget. The service life extension programs are being undertaken today to ensure that the future mission requirements of existing aircraft can be fulfilled and the airworthiness of the aircraft is maintained until out of the service date. The programs for extending the service life propose different methods for analyzing of all the occurrences that can be found at aircraft structures and for synthesis of evaluated results. These programs enable a certain prediction of the remaining service life beyond originally designed service life.

The designed service life is the period of time (e.g. flight cycles, years, flight hours, landings, etc.) established at design, during which the structure is expected to maintain its structural integrity when flown to the design loads/environment spectrum. The service life extension programs, in other words programs for extending the aircraft service life, consist of a process of defining and executing the recommended additional procedures as aircraft monitoring and maintenance with required possible additional constraints and limits for the further aircraft service during the period of extended life, with issuing the appropriate certificate for airworthiness.

During the service of an aircraft throughout the designed service life and approaching to the time when the designed service life is running out the reliability could be diminished or the number of equipment or avionic failures could be increased or even the failure of the airframe parts and assemblies could happen. Equally, whilst the operational life is increasing, various aging effects take place and impair the structural and functional integrity of a highly aged aircraft structure and subsystems even before their design life is reached.

The process of aircraft aging and aging of the aircraft equipment is the process when the integrity of structure or the integrity of equipment functionality is continually degraded due to the exposure to environment in which the aircraft is in use.

There are different mechanisms that independently or in combination influence aging of an aircraft or aging of its equipment, such as:

- Exposure to normal atmosphere conditions or to atmosphere with a higher degree of salinity, temperature, different chemical compounds, water/vapors, oils, fuel 
vapors or solutions, grease, and/or UV radiations that can lead to aging, corrosion, increasing brittleness, swelling, overheating, melting or any other degradation of material characteristics.

- Exposure to vibrations and environment with negative acoustic characteristics may cause a damage due to fatigue, wear, fracture, etc.

- Maintenance of aircraft, storing or conserving of aircraft with the influence of store conditions according to the proposed manufacture procedure or proposed work practice,

- Activities provided for aircraft maintenance and equipment maintenance can cause an incidental and unwanted damage of airframe and other equipment components.

The aging process of an aircraft structure and its subsystems cannot be prevented but the velocity of aging can significantly be reduced by the following:

- Identifying critical areas and components where aging could have serious consequences,

- Reviewing the current aging process of subsystem components in a highly aged aircraft or of a highly aged components,

- Reviewing the current maintenance procedures and policy regarding the aging problematics,

- Improving the preventive maintenance actions in order to address aging in an early stage.

\section{Service life extension program for SUPER GALEB G-4 aircraft structure}

G-4 Super Galeb aircraft is a product of the former Yugoslavia (SFRJ). Prototype of this aircraft had its maiden flight in 1978. Serial aircraft were produced since 1984 until 1992. Aircraft of this type have been in use in air forces of several countries, such as SFRJ, Burma, Montenegro, Republic of Srpska (since 1992 until 1995). This type of aircraft was produced in more than 90 planes, which could be differentiated as prototypes, preserial producing planes (six planes) or as serial producing planes. Today these types of aircraft have been in use in Serbian Air Force and in foreign air force. Designed service life for military service aircraft is from 20 to 25 years or 5000 flight hours.

During the designed service life of G-4 Super Galeb aircraft the conditions of Time Between General Overhaul (TBGO) and overall service life, and the allowed total flight hours between two consecutive general overhauls, have been slightly changed. However, due to different reasons, this type of aircraft has not reached maximum allowed flight hours during its designed service life. The reasons for that are varied, but only a few are related to the technique, and majority are related to other reasons such as political, administrative, organizational, etc. Due to these influences the aircraft of this type in the Serbian Air Force have barely $30-50 \%$ of flight hours out of total designed service life (6000 flight hours). Therefore, the research using the exact technical methods led by the Military Technical Institute (VTI) started in 2009 with the aim to evaluate if it is possible, and for how long, to extend the service life of the airframe and airplane.

According to this research, the service life extension program for G-4 Super Galeb aircraft structure has been developed in VTI. The program defines the NDI methods, modern numerical structure analysis, and simulation analysis as a basis for determination of the service life extension. The program precisely defines and quotes all elements and methods that have to be performed as well. The NDI methods, modern numerical structure analysis, and simulation analysis are used for the prediction of the remaining service life in service life extension program for aircraft beyond its designed service life.
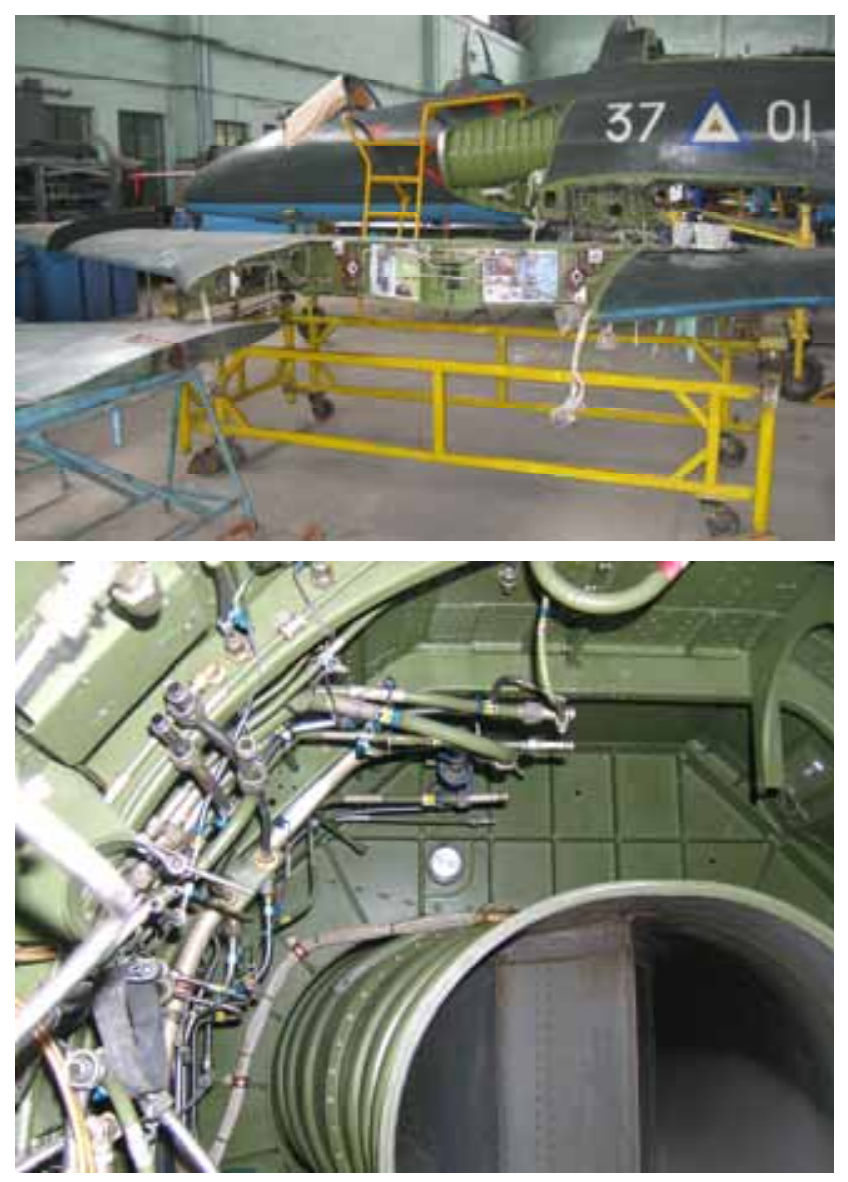

Figure 1. G-4 Super Galeb aircraft prepared for inspection (example)

In scope of the G-4 aircraft structure service life extension program the conditions of the storage of the aircraft were also taken into consideration. As the aircraft of this type spend less than $1 \%$ of their total life flying, the conditions of the hangars are important regarding deterioration effects: warm and dry hangar conditions have positive effects compared to the aircraft standing outside. Otherwise, wet and cold hangar conditions have negative effects compared to the aircraft standing outside or standing in warm and dry $r$ acid rains, UV radiation, windstorm, etc. All these conhangars. Aircraft standing outside hangars during their no-flight hours are exposed to dry or wet conditions, salty oditions have to be taken into consideration during the implementation of the aircraft structure operation life extension program.

\section{Super Galeb G-4 Aircraft Structure Service Life Extension Program for foreign air force}

An integrated service life extension program for G-4 Super Galeb aircraft was defined between the foreign customer and the project type owner (Military Technical Institute - VTI) with the aim of extending the operational life of the aircraft under defined budgetary conditions and tight timescales.

VTI has defined aircraft structure service life extension program as a basis for extending aircraft structure service life. The program involves the use of the following methods: 
- Nondestructive Inspection (NDI),

- Stress analysis with the aspect of fatigue and fracture mechanics,

- Flight loads and load cycles analysis,

- Experimental testing of aging G-4 structure specimens,

- Software development for prediction of remained service life beyond designed service life.

The established program encompasses the structure and equipment review, review of the in-service usage, investigation of the reported in-service problems (if they exist) and related statistics, master inspection of all aircraft subsystems in G-4 aged aircraft. Additionally, the program is conducted to establish revised in-service operational conditions.

The main role in this service life extension program belongs to the Nondestructive Inspection (NDI). Nondestructive inspection, according to [5], is an inspection process or a technique that reveals conditions at or beneath the external surface of a part or material without adversely affecting the material or part being inspected. The overview of some NDI methods was shown in this paper as well as their advantages and drawbacks. The part of service life extension program for G-4 Super Galeb aircraft was shown in the second part of the paper, especially airframe inspection made by the NDI methods.

\section{Operational, environmental, climate and other influences on aircraft during the service}

Many different challenges can cause problems to the aircraft service during whole its life cycle. The further list can describe the complexity and difficulties that aircraft are exposed to and have to overcome during the long service life cycle [6-8]:

Operational conditions: can be changed during the lifetime of the aircraft. For the new and aged aircraft where life extension is an issue the current and future planned operational conditions need to be investigated and compared to the original design requirements. This can be done by the engineering assessments or if the conditions cannot be established on a theoretical basis by programs that can measure operational loads. These programs can be used to calculate the existing clearances and life potential or to provide a basis for the further qualification testing. These programs are very expensive and time consuming and using these programs should be taken early enough to ensure that the results for any particular aircraft are available on time.

Usage history, life consumption: the usage history needs to be established and this requires the availability of a complete in-service documentation in advance. Unfortunately, it has been experienced that it is sometimes very difficult to get all the information necessary to assess service life and life consumption. For the safety relevant and life limited components this causes many problems as it might not be possible in these cases to establish whether the equipment is already life-expired or not.

Repairs and concessions: the influence of repairs and concessions on life limitations needs to be assessed. Normally, minor concessions should not affect life limits, but if the operational conditions have changed in the past of the aircraft, the classification of concessions needs to be reassessed.

Obsolescence: is a problem which becomes more problematic with increasing the age of the aircraft. Materials and components, which have been used in the original design, could be no more available and this could require redesign and requalification activities if no proofed and certified alternatives exist.

Availability of the original supplier: for most of the major structure parts and equipment there was only one supplier selected, who has designed and qualified the item. This supplier might have disappeared or is no more able to produce the required component or subassembly. The introduction of an alternative supplier will cause problems in terms of time and costs. Dependency on one supplier is critical but usual.

Costs for the procurement of the equipment: for the procurement of the equipment for replacing an aged or lifeexpired part after 20 years in service that is no more existent, design and qualification of a new component are necessary.

Inspections and inspection efficiency: with the aging of the aircraft the aging effects will increasingly require inspections of critical parts, components and subassemblies to ensure that any aging effect will not lead into a safety hazardous situation. The success of inspections is very dependent on the selection of the appropriate methods, availability of the required equipment, clearly defined inspection procedures, availability of the trained personnel.

Maintenance documentation: existing maintenance procedures, which do not address aging as experienced by investigations or sampling, need to be revised. Requirements or recommendations of the equipment manufacturer, defined during the life extension process, should be included.

Failure and maintenance reporting systems: most aircraft users are maintaining comprehensive databases to collect and evaluate failure and maintenance reports for the whole aircraft down to the equipment and component level in order to identify unreliable component problem areas. However, in-service data collection systems are mainly defined by the aircraft users and reflect their specific needs and points of interest. The definition of data elements and the level of detail may significantly vary, even between different users of the same aircraft type. Consequently, the probability that the failure and maintenance data collected during the service are compatible with the design analysis and predictions is fairly low. The value of an in-service database can only be as good as the entries. It is therefore important to consider that any analysis or curves derived from databases need a specific interpretation or should be taken with care.

Statistical analysis of a large number of world's aircraft has so far shown that the problems with aircraft are increased with time. The problems are in the majority related to: corrosion, wear and tear, leakage, contamination, porosity, brittleness, contact damage, isolation damage, etc.

Aircraft in general is subjected to rather severe environmental conditions. The temperature, UV radiation and pollutants are known to play a major role in degradation of the aircraft skin, coating, parts and systems [8]. The air temperature differences exceed $100^{\circ} \mathrm{C}$, ranging from $-60^{\circ} \mathrm{C}$ at flying altitude of $10 \mathrm{~km}$ to over $50^{\circ} \mathrm{C}$ in airports located in tropical regions. Moreover, it is known that the coatings and skin surfaces temperature is much higher than the air temperature, especially for dark colors, such as military aircraft. Apart from the temperature and $\mathrm{UV}$, wetness is also a known factor influencing the life and state of aircraft in general.

Much of training airfields of foreign air force for G-4 aircraft lies between the Tropic zone and the Equator. It lies in the monsoon region of Asia, with its coastal regions 
receiving over $5000 \mathrm{~mm}$ of rain annually. Annual rainfall in the delta region is approximately $2500 \mathrm{~mm}$, while the average annual rainfall in the dry zone in central part of country is less than $1000 \mathrm{~mm}$. Coastal and delta regions have an average maximum temperature of $32^{\circ} \mathrm{C}$. Inspected G-4 Super Galeb aircraft are based in air force bases and used in coastal regions where the temperature, humidity and salinity are very high. From June to October there is the monsoon season, with high rainfalls. From June to August, rainfall can be constant for long periods of time, particularly on the Bay of Bengal coast with a very high humidity range: from $84 \%$ to $97 \%(100 \%)$. These severe environment conditions have been taken into account during making a plan for Service life extension program. Fig.2 shows two main environmental conditions (temperature and relative humidity) that influence the airframe during service life. According to Fig.2 it could be concluded that climate conditions for the airplane in-service are rather severe.
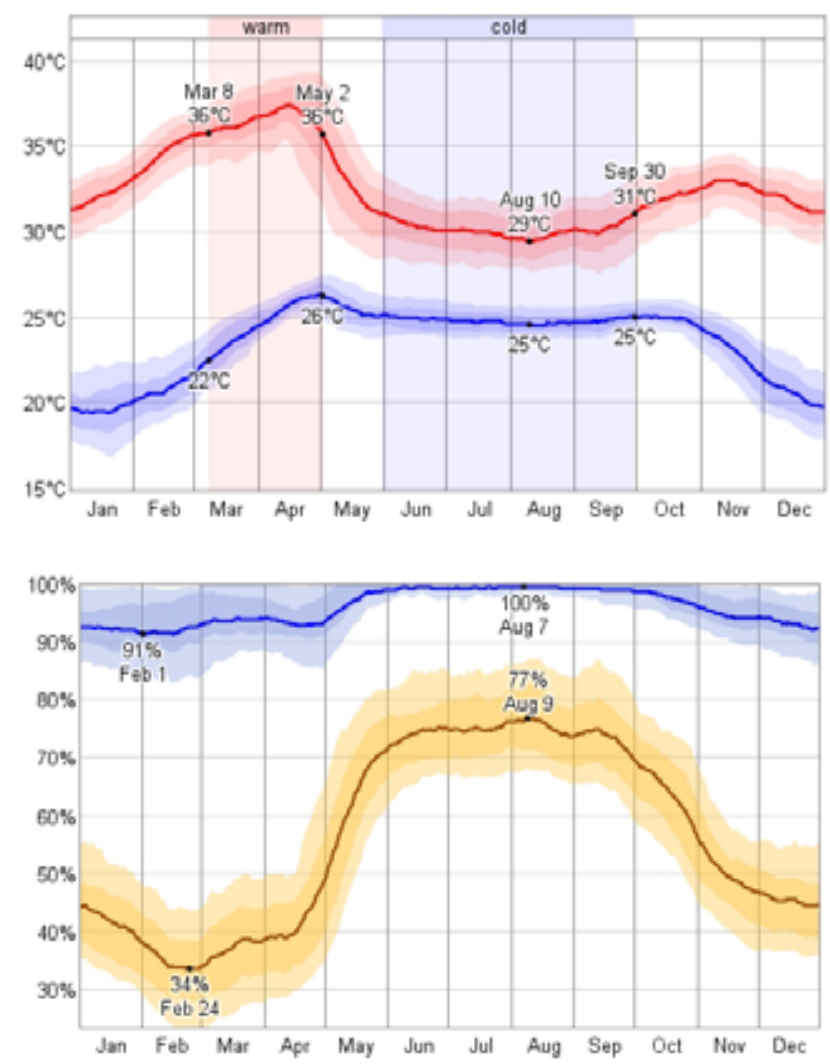

Figure 2. Average daily high and low temperature (above); average daily high and low relative humidity (below) in G-4 training airbase

\section{Consideration of corrosion as the main influence factor}

Corrosion is the deterioration of a material or its properties due to a reaction of that material with its chemical environment. Corrosion has always been recognized as a major factor in aging aircraft maintenance. Each air force has addressed it differently, according to its operating environment and perceived needs. With the extension of the operation life, the problem is becoming increasingly important and has received more and more attention of the researchers.

Corrosion and corrosion fatigue are recognized as significant damage mechanisms to the aircraft structures. Corrosion and corrosion fatigue failure process of an aircraft structure are directly concerned with many combined factors, such as load, material characteristics, corrosive environment, and so on. The damage mechanism is very complicated, and there are both randomness and fuzziness in the failure process. Corrosion and fatigue, separately or in combination, are serious threats to the continued safe operation of aircraft, Figures 3 and 4 . Although the corrosion has a severe impact on a structural integrity, the airworthiness regulations and requirements have limited instructions regarding corrosion, noting that each part of the aircraft has to be "suitably protected against deterioration or loss of strength in service due to any cause, including weathering, corrosion and abrasion" [5].

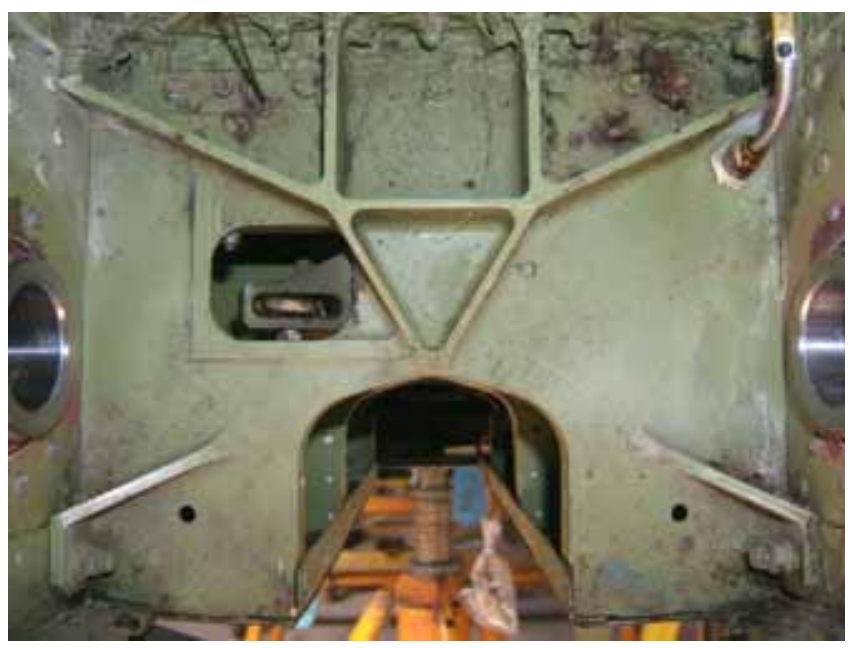

Figure 3. Nose landing gear bay with local points of surface corrosion

The Federal Aviation Administration (FAA), and former European Joint Aviation Authorities (JAA) have had guidelines on how aircraft should be designed and maintained to minimize the risk of failure from fatigue damage [1]. The ability to assess the impact of future corrosion on the structural integrity, alone or acting in concert with fatigue, is difficult. A framework to assess the effects of corrosion in combination with fatigue on the structural integrity has been under development.

\section{G-4 SUPER GALEB aircraft structure nondestructive inspection}

At first, an overall system inspection procedure was established to assure the adequate nondestructive inspection of structural components for which it is determined that it is necessary to have the NDI acceptance. This system inspection procedure included inspections throughout all phases of the procedure. In scope of this procedure, all structure parts that have to be inspected by the NDI methods were defined in order to detect the real structure situation. For that purpose, the procedure along with the names of the parts to be inspected, the appropriate NDI methods were defined for particular structural parts and for inaccessible areas of the aircraft assemblies as well. All airframe parts essential for aircraft strength and functionality were included in the list.

The NDI inspection procedure for G-4 Super Galeb airplanes provided for inspection of main structural parts and assemblies, such as wing and fuselage attachments, nose landing gear attachments and strut, engine-to-fuselage attachments, cannon pod attachments, attachments for joining central to rear part of fuselage, attachments for joining rear part of fuselage assembly to vertical tail, air 
brake attachments, horizontal tail shaft, horizontal tail shaft, main landing gear attachments and struts, main wing spars, rear wing spars, all wing control attachments and brackets, flaps brackets, flaps brackets for attachment of hydraulic cylinder, aileron brackets, vertical tail attachments joining tail to fuselage, vertical tail attachments joining stabilizer and rudder, rudder attachments, rudder torsion shafts, all bolts and screws, conical bearings, nuts, special bolts for joining main structural parts and attachments, and others.

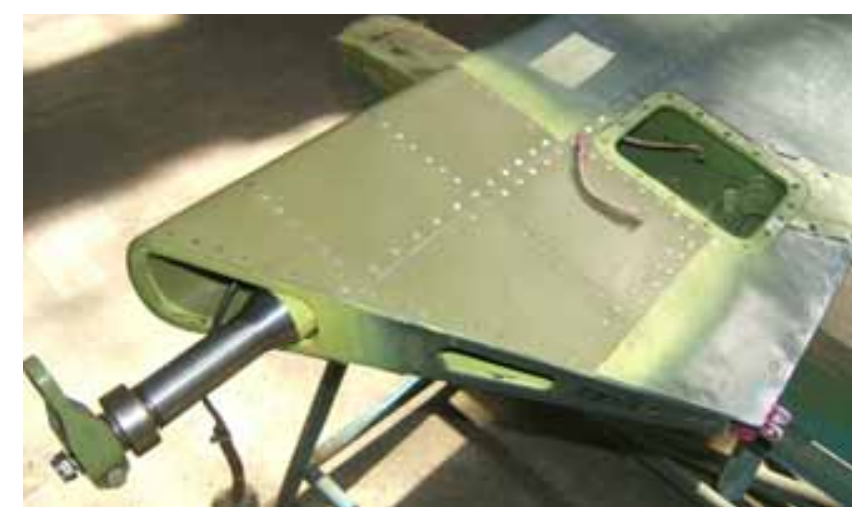

Figure 4. Repaired rudder (after the elimination of severe steel corrosion) ready to be attached to the airplane

Only the results of inspection as a basis for aircraft service life extension were discussed in this paper. As far as the detection of the possible mechanical damages of structural parts which make reduction of strength of particular structural parts the appropriate strength is evaluated using appropriate dimensioning with the aspect of the parts strength and the prediction of remained service life.

The structure and system engineers have reviewed the criticality of main and secondary structure items. It became obvious that not all structure items need specific actions for life extension. For example, the attachment structure items are generally designed to static stress conditions, loads resulting from crash and maneuver accelerations and stiffness requirements. During design, good design practices were used which resulted in equipment support that are sufficiently robust for any normal aircraft lifting and flight loads. In addition, life extension of structural components of the landing gear and its back-up structure are of a special concern, as it is known that the operational loading conditions have changed during the lifetime of the aircraft, for instance due to the increased aircraft weights.

\section{NDI techniques, methods and equipment}

NDI techniques, methods and equipment used during the inspection of foreign air force G-4 Super Galeb aircraft structure were shortly described in this chapter. The diagnostic of main airframe parts status in order to get a basis for the extended service life prediction was accomplished by the NDI methods, such as:

- Visual control -VC,

- Endoscope visual inspection - EVI,

- Dye penetrant inspection - PI,

- Eddy current inspection - ECI,

- Ultrasonic inspection - UI.

Visual control $-V C$ was conducted of all airframe parts by devices such as $5 \mathrm{x}$ Glass magnifier, Endoscope and 100x Optical microscope (Fig.5). Glass magnifier and Optical microscope were used for the assessment of a corrosion depth at the places where the corrosion was detected. These devices were used to make a good prediction of corrosion depth at the places where the corrosion was detected or could be detected [5].

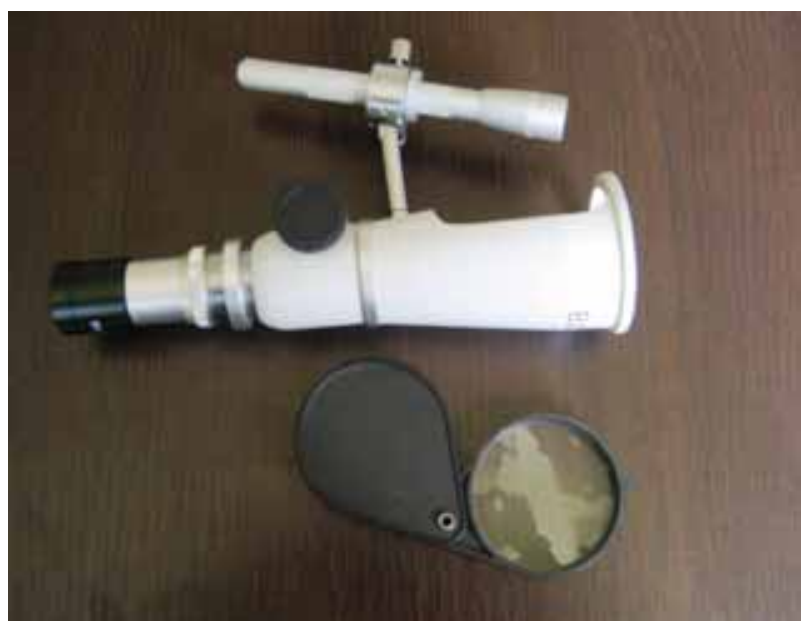

Figure 5. Optical microscope $-100 \mathrm{x}$ and Glass magnifier $-5 \mathrm{x}$

Endoscope visual inspection - EVI was accomplished at all inaccessible places such as inner wing areas (integral fuel tanks, void spaces behind rear spar), and at counterparts of fittings attached to main spar, integral fuel tanks, ailerons, flaps and rudder, and in internal part of fuselage assembly among lower milled plate, fuselage skin, air intake, and upper milled plate. The primary goal of these inspections is to detect all possible hidden defects and corrosion lying at inaccessible voids where one could reach only through a small revision and technological openings.

Optical devices are of a great importance for the complete detection of surface defects and for definition of location and size of defects. By this device, one could easily find cracks and location of corrosion, Fig.6.

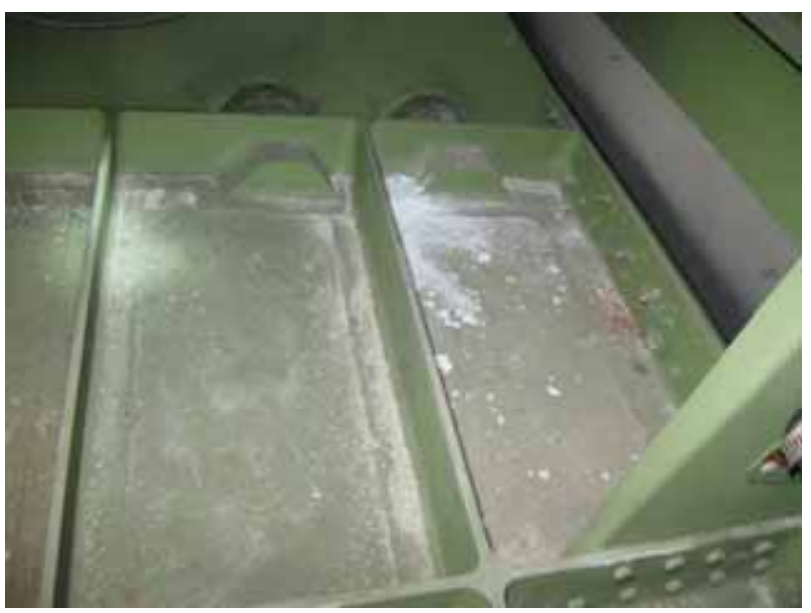

Figure 6. Main fuselage structural assembly attacked by local surface corrosion

Endoscope was used to perform the inspection of all inaccessible places, inner wing areas, attachments situated in narrow areas where one could reach, inner areas of all control surfaces (ailerons, flaps, rudder, etc.), lower fuselage milled plate in order to find hidden defects, cracks or corrosion.

Wireless video endoscope (PCE-VE 500) is intended for the inspection of assemblies in automotive and aeronautical industry, for control of systems, installations, and equipment in inaccessible spaces where the precise visualization is needed. The device requires orifice $5,5 \mathrm{~mm}$ in diameter for probe entrance and with wireless 
transmission it enables real time visualization on 3,5 inches TFT display. Video and images recorded by PCE-VE 500 (Fig.7) endoscope enable a detailed overview and analysis using a display or a computer of all inaccessible voids to staff of other NDI equipment. With a connection cable, included video endoscope can be connected to a display to see the image on a larger display. Images or videos can be registered on the SD card for the further analysis on a computer. Both the endoscope and the display are powered by an accumulator. Wireless video endoscope was especially used for the control and inspection of all possible defects placed in the G-4 Super Galeb aircraft inner areas of wing integral fuel tanks and in void spaces behind rear wing spar.

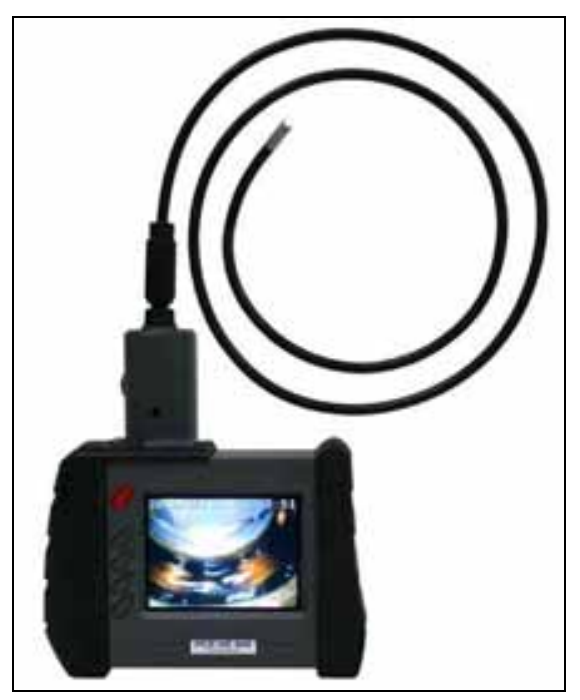

Figure 7. $P C E-V E 500$ Wireless video endoscope

Dye penetrant inspection - PI was carried out on all of aircraft fittings, attachments, and brackets of fuselage, wings, ailerons, flaps, horizontal and vertical tail assemblies, nose and main landing gears and connection parts of the central fuselage and aft fuselage assemblies, air brakes and rudder in order to find any possible surface defects or cracks.

The basic purpose of penetrant inspection is to increase the visible contrast between a discontinuity and its background. This is accomplished by applying a liquid of high penetrating power that enters the surface opening of a discontinuity. Excess penetrant is removed and a developer material is then applied that draws the liquid from the suspected defect to reveal the discontinuity. The visual evidence of the suspected defect can then be seen either by a color contrast in normal visible white light or by fluorescence under black ultraviolet light.

Set of penetrant fluids is used for revealing of surface defects in metal materials made from ferrous or nonferrous alloys. Inspected surface has to be well cleaned from anticorrosion protection layers and any other compounds or sealants. Set of penetrant fluids is composed of Penetrant, Solvent, Cleaner, and Developer.

After the application of penetrant to inspected surface, it easily penetrates into surface opening of a discontinuity and remains in cracks. Excess of penetrants is removed after treatment and the developer then has to be applied. The developer has such properties to extract penetrant from material cracks, which causes the penetrant can be seen as a red colored contrast to a white colored surface, Fig. 8.

Dye penetrant inspection - PI was performed with penetrant FLUXO P125, solvent cleaner FLUXO S190, developer FLUXO R175 with artificially generated lights up to 500 lux during control. Penetrant time was 15 minutes.

Eddy current inspection - ECI inspection was done to all main attachment points such as wing to fuselage, wing skin rivets, main fuselage frames and bulkheads, engine mountings, connection bolts, vertical and horizontal tail unit's attachment points, and all magnetic ferrous alloys in order to find any possible cracks and surface defects. Eddy current is used to detect surface cracks, pits, subsurface cracks, and corrosion on inner surfaces.

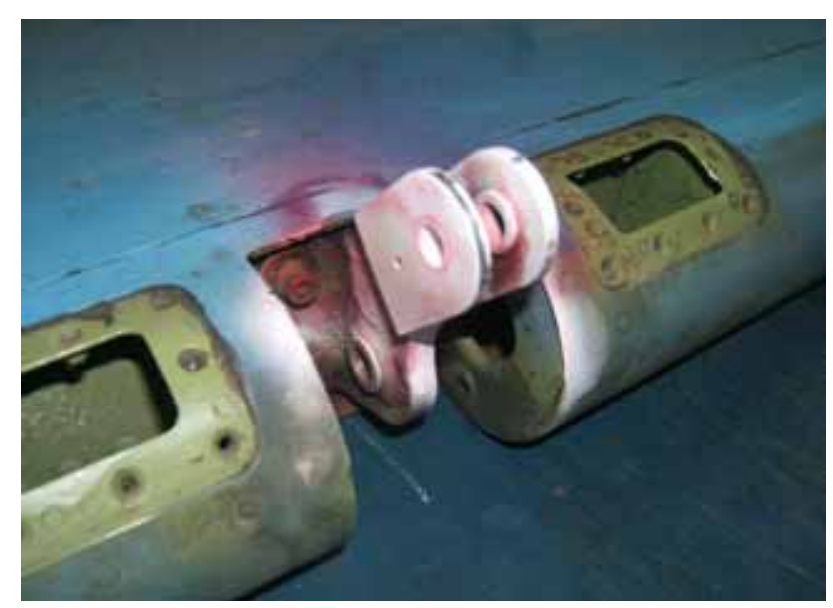

Figure 8. G-4 aileron attachment points treated by penetrants

Eddy current Defectoscope VD-10 A and probe P15, used during the inspection, are intended for the precise control and inspection of metal products made from ferromagnetic and non-ferromagnetic alloys (aircraft structural parts and assemblies during the service and general overhaul). Eddy current defectoscope with the appropriate probes can detect surface cracks and defects. Inspection with eddy current defectoscope can be used for surfaces covered with electrically nonconductive materials. Defectoscope uses parametric probes working at 0,8 do 2 $\mathrm{MHz}$. Sensitivity of the defectoscope depends on the type of probe, defect depth, defect volume, direction of propagation of defect, defect type, conductivity, and other physical or mechanical characteristics of the inspected material.

Ultrasonic inspection -UI Ultrasonic inspection is a NDI technique that uses sound energy moving through the test specimen to detect flaws. The sound energy passing through the specimen will be displayed on a Cathode Ray Tube (CRT), a Liquid Crystal Display (LCD) computer data program, or video/camera medium. Indications of the front and back surface and internal/external conditions will appear as vertical signals on the screen or nodes of data in the computer test program. Ultrasonic inspection can easily detect flaws that produce reflective interfaces. Ultrasonic inspection is used to detect surface and subsurface discontinuities, such as cracks, shrinkage cavities, bursts, flakes, pores, delamination, and porosity. It is also used to measure material thickness and to inspect bonded structure for bonding voids [10].

Ultrasonic inspection was performed for lower milled fuselage plate in order to detect remaining material thickness under corrosion layer and for corrosion thickness.

Defectoscope UCD-50 is intended to ultrasonic defectoscopy and for ultrasonic thickness dimensioning. Internal memory enables archiving of data for two types of display patterns, "A" scan and "B" scan, for parameter settings, and inspection results. Functionality of the ultrasonic defectoscope is based on a different propagation of ultrasonic waves through the inspected material where 
the defectoscope can detect voluminous and other material defects. Ultrasonic inspection can be used for materials with anti corrosion nonconductor protection films. Defectoscope can use a range of different probes working at 0,8 do $15 \mathrm{MHz}$, which depends on the object of inspections. The places where the corrosion was detected by a visual control, such as lower fuselage milled plate, was a necessity to establish the depth of the corrosion. For this purpose, the Defectoscope UCD-50 was used. Using this device was an efficient way to define remained depth of impacted lower fuselage milled plate.

\section{Experimental and computation testing of the aging G-4 structure specimens}

In scope of the research for extension of the operation life of G-4 Super Galeb aircraft structures a number of experimental testing were conducted. Experimental tests were done using original airframe parts from the planes that were produced 25 and more years before the experiments, precisely at the beginning of the serial production of this type of aircraft. Experimental tests were conducted with main fuselage bulkheads (attachments of wings to fuselage). Test loads used for this type of experiment were static loads with cyclic loads simulating several thousand hours of flights. These types of tests were executed on servo hydraulic MTS system. Fig.9 shows a part of fuselage bulkhead during tests.

Fatigue test of the aircraft bulkhead no.18 (main wingfuselage joint of G-4 Super Galeb aircraft) was carried out under loading spectra that is experimentally determined during the flight of N-60 aircraft.

Fatigue test is realized using servo hydraulic MTS system as shown in Fig.9. Realized fatigue test of this frame corresponds to 2000 hours of flight. After the realized fatigue test of this bulkhead the complete structure was with no initial cracks recorded. In this manner, it confirmed the residual life for the additional 2000 hours of flight.

The tests accomplished showed that main structural parts did not change its mechanical properties after more than 25 years of service. The structural elements subjected to load cycles simulating load during real aircraft service also did not undergo any damage. To determine the residual life of critical aircraft structural components, computation methods are used. These methods are based on combining the Finite Element Methods (FEM) for stress analyses, Fig.10, with "in-house" software for the initial fatigue life estimations, see Table 1.

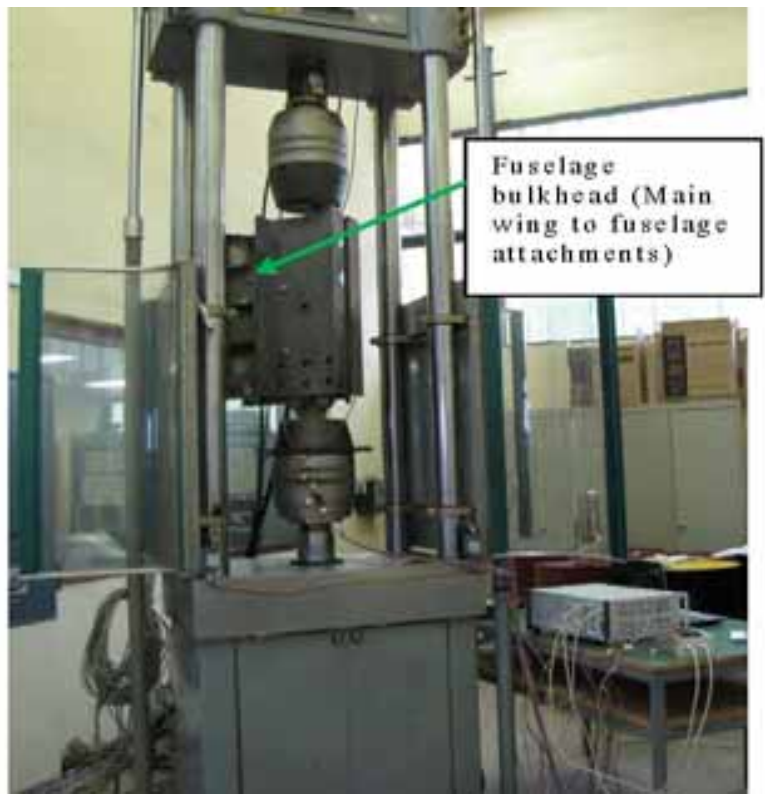

Figure 9. G-4 Fuselage bulkhead during the experimental testing using MTS [6]

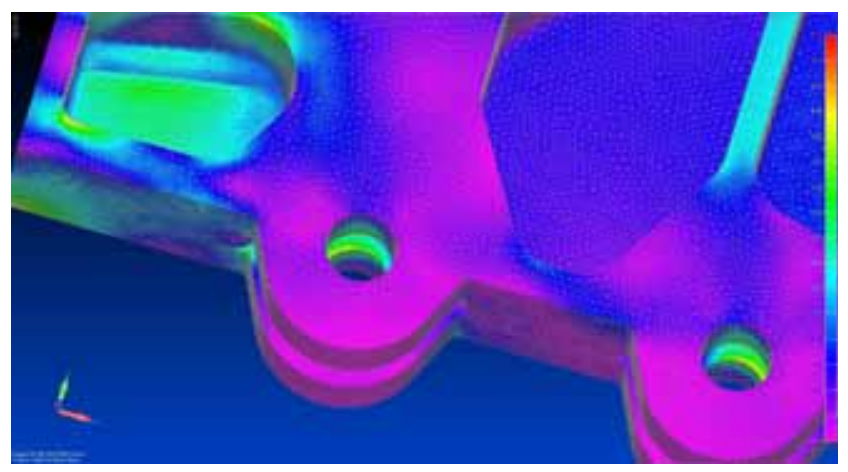

Figure 10. Stress Analysis of the bulkhead no. 18 of G-4 Super Galeb aircraft

Table 1: Representative results of a fatigue life estimation for the structural component using "in-house" software

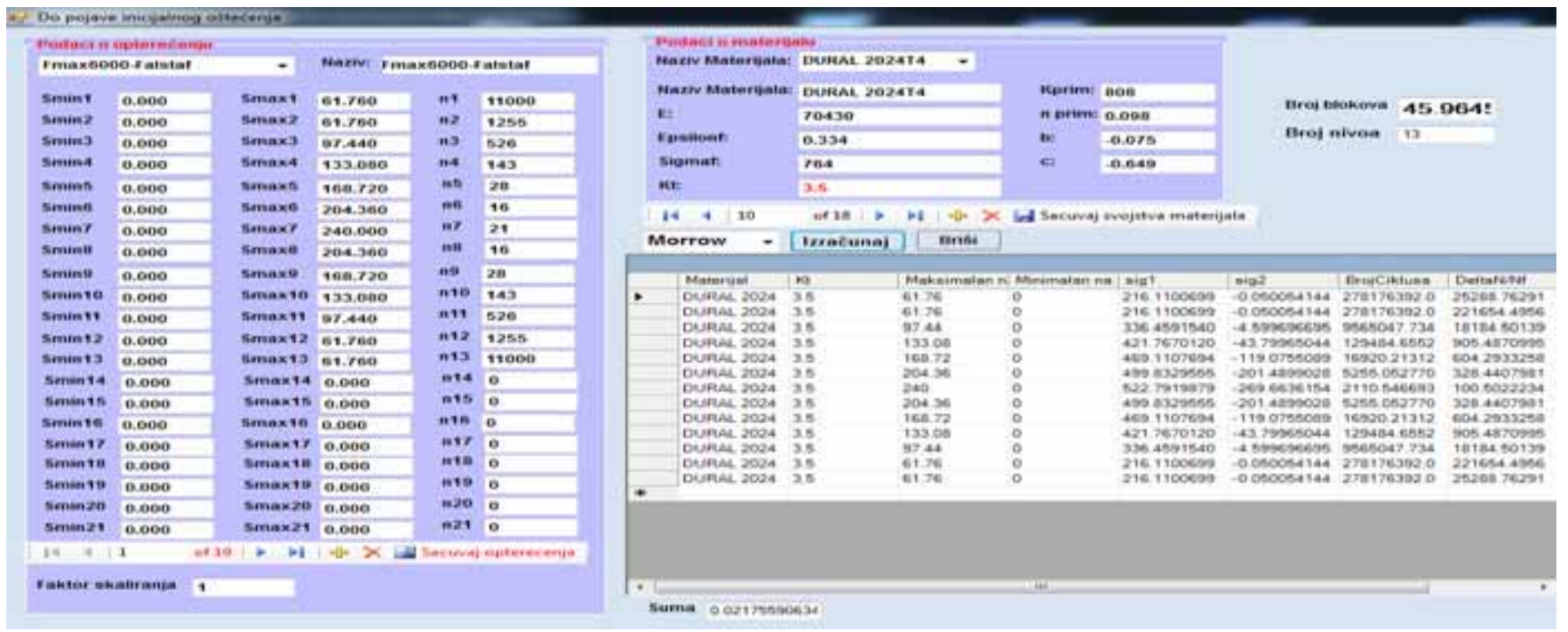




\section{Analysis of results attained by the NDI inspection of an aircraft structure}

Detailed control and inspection of all main airframe parts and assemblies showed that no damages were detected, which could have been caused because of the fatigue or excess of limits of the flight loads. Visual control using the NDI methods showed that there were only several local surface corrosion areas located at the main structural elements [8-10].

Based on the NDI tests conducted on airplanes structures that have been in service for more than 25 years it is evaluated that there were not any damages of the vital aircraft structural elements as an influence of service loads or corrosion process or any other cause $[11,12]$. This represents a basis for extending the time period for further service of the aircraft structures.

\section{Conclusions}

The process of an aircraft aging, aging of its structure and equipment cannot be stopped but it could be rather diminished using several practical approaches, such as:

- identification of critical points based on computation stress/strength analyses, components, and areas where the consequence of aging can cause a serious outcome, - visual control and analysis of the aging process at the oldest airplanes in service or equipment components,

- analysis of the official maintenance procedures addressed to the aging problem,

- improving of the protective maintenance methods in order to focus on aging in an early phase of its appearance.

Understanding the influence of different factors on degradation of structure integrity is very important in order to manage corrosion occurrences on an aging aircraft. Programs for the extension of the operation life of an aircraft have to address to the procedures and practice which improve surface protection, controlling, inspection, and maintenance of the aircraft during service. The main role in the procedures of controlling and inspection of airframes belongs to the NDI methods that have to be used regularly and timely in an appropriate way.

Despite of severe climate conditions in which the G-4 airplanes operate, the structure and equipment of the aircraft show that the quality of aircraft fabrication, constructive material, surface treatment and protection were accomplished very well and only a small portion of surface corrosion and other flawless were detected during the aircraft inspection. Based on the NDI results evaluated after the inspection of all provided airplanes the conclusion can be drawn that the unacceptable defects were not detected on all vital airplane structural elements. The inspection results showed a good conformation to the appropriate requirements and the results meet the requirements for the further safe aircraft service.
Beside the NDI testing that has been shortly presented in this paper, and other fatigue testing accomplished on G-4 Super Galeb vital airframe parts, it leads us to a conclusion that the service life of the inspected G-4 aircraft structures can be extended. The adequate recommendations for the additional revised maintenance and inspection programs and no crucial limitations have been recommended to enable a formal certification of the aircraft for the extended period.

The importance of the process of research tasks about the possibility of extension of service life of the aircraft is that it enables the further use of the plane and opens the possibility of modernization of this type of aircraft.

\section{References}

[1] MIL-HDBK-6870B, Nondestructive inspection program requirements for aircraft and missile materials and parts, 2012,

[2] MIL-HDBK-1823A, Nondestructive evaluation system reliability assessment, 2009,

[3] IK 494-13-Reports IK (In Serbian), RD Dijagnostika d.o.o., 2014, Beograd.,

[4] SANKARAN,M., SHI,P.: Corrosion fatigue reliability of aging aircraft structures, Prog. Struct. Engng Mater. 2001; 3: pp.188-197 (DOI:

[5] Federal Aviation Regulation, Part 25, Protection of Structure, Airworthiness Standards: Transport Category Airplanes, Sec. 25., p.609.,

[6] MAKSIMOVIĆ,S., BURZIĆ,Z., GEORGIJEVIĆ,D.: Strength analysis of aircraft structures with respects to fatigue, Military Technical Institute, Belgrade, KumNTI, 2010, Vol.XLIV, No.4, ISSN 1820-3418, ISBN 978-86-81123-37-9 (In Serbian).

[7] BLECH,G.: Aging Aircraft Subsystems Equipment life Extension within the Tornado Program, Panavia Aircraft GmbH, Germany, RTO AVT Lecture, "Aging Engines, Avionics, Subsystems and Helicopters", RTO EN-14.

[8] GUSEVA,O., BRUNNER,S., RICHNER,P.: Service life prediction for aircraft coatings, Polymer Degradation and Stability, 2003, Vol. 82, pp.1-13.

[9] MAKSIMOVIĆ,S., DOŠIĆ,R., VASIĆ,Z.: Some aspects of operation life extension of aircraft structures, 6th International Scientific Conference on Defensive Technologies OTEH 2014, Military Technical Institute, Belgrade, SERBIA, 09.-10.October 2014, Proceedings ISBN 978-86-81123-71-3, pp.185-191

[10] MAKSIMOVIĆ,S., VASIĆ,Z: G-4 aircraft No. 3701 and 3702 structure analysis as a part of service life extending program, (In Serbian), VTI report, V9-815, 6608525, Beograd 2015.

[11] OGNJANOVIĆ,O., MAKSIMOVIĆ,K., STAMENKOVIĆ,D.: Effects of Thermal Gradients on Fracture Mechanics Parameters, Scientific Technical Review, ISSN 1820-0206, 2013, Vol.63, No.3, pp.17-21.

[12] BOLJANOVIĆ,S., MAKSIMOVIĆ,S., CARPINTERI,A.: Fatigue Life Evaluation of Damaged Aircraft Lugs, Scientific Technical Review, ISSN 1820-0206, 2013, Vol.63, No.4, pp.3-9.

\section{Program produženja veka upotrebe strukture aviona}


usmerena na primenu NDI metoda. U ovom radu su prikazane metode i praktični koraci koji umanjuju negativan efekat korozije. Ovi koraci omogućuju da se izvrši produženje veka upotrebe strukture preko granice definisane projektnim uslovima strukture aviona.

Ključne reči: avion, struktura letelice, trup aviona, korozija, korozioni zamor, ispitivanje bez razaranja, ispitivanje veka trajanja, procena veka trajanja.

\title{
Programme du prolongement de la durée de service pour la structure d'avion
}

Les performances d'avion, ses systèmes ainsi que les caractéristiques des matériaux peuvent être réduits considérablement à cause de l'influence des conditions d'environnement dans lesquelles l'avion s'utilise pendant l'exploitation. Les caractéristiques des matériaux comme acier et les alliages d'aluminium peuvent être dégradées par les conditions d'environnement (température, humidité, radiation UV, pollution, etc.) qui influent considérablement sur l'intégrité et la sécurité de la structure d'avion. Parmi les conditions d'environnement l'effet de corrosion sur l'intégrité de la structure d'avion est l'un des paramètres clé pour la conception de point de vue des endommagements permis et à cause de cela il doit être analysé attentivement. La corrosion et les fractures causées par la fatigue de corrosion de la structure d'avion dépendent directement de plusieurs facteurs tels que la charge, les caractéristiques des matériaux, l'influence du milieu corrosif, etc. Dans ce papier l'attention est prêtée à l'application des méthodes sans destruction (NDI) dans le processus de prolongement de la durée de service de structures des avions qui sont en exploitation. Les méthodes de computation et les méthodes expérimentales NDI ont été utilisées comme une part de programme pour le prolongement de la durée de service de l'avion G-4 Super Galeb en exploitation par l'Armée de l'air pendant plus de 25 ans. $L$ 'accent particulier est mis également sur l'application des méthodes NDI. Les méthodes et les pas pratiques qui diminuent l'effet négatif de corrosion sont présentés dans ce papier. Ces pas permettent le prolongement de la durée de vie de la structure d'avion au-delà de la limite définie par les conditions de sa conception.

Mots clés: avion, structure d'aéronef, fuselage d'avion, corrosion, fatigue de corrosion, examen de la durée de vie, examen sans destruction, estimation de la durée de vie.

\section{Программа продление срока службы конструкции самолёта}

\begin{abstract}
Характеристики самолёта, его системы, а также и характеристики его материалов могут быть значительно снижены из-за влияния внешних условий, в которых проходит эксплуатация самолёта. Характеристики материала - стали и сплава алюминия могут стать значительно хуже из-за влияния внешних условий (температуры, влажности, УФ-излучения, загрязнения и.т.д.), которые серьёзно влияют на целостность и безопасность конструкции самолёта. Из всех условий окружающей среды, влияние коррозии на целостность структуры самолётов является одним из ключевых параметров при проектировании в плане допустимых повреждений и, следовательно, должно быть тщательно проанализировано. Коррозия и переломы конструкции самолёта в результате коррозионной усталости, напрямую связанны и зависят от нескольких факторов, таких как нагрузка, характеристики материала, влияние коррозионной окружающей среды и других. В этой статье внимание сосредоточено на применении метода неразрушающего контроля (NDI) в процессе продления срока службы конструкции самолётов, которые находятся в процессе эксплуатации. Методы расчёта и экспериментальные методы NDI были использованы в качестве части программы для продления срока службы конструкции самолётов Г-4 Супер Галеб, которые находились в эксплуатации ВВС на протяжении более 25 лет. Особое внимание в этой работе сосредоточено на применении методов NDI. Методы и практические шаги, которые снижают негативные последствия коррозии, представлены в этой статье. Эти шаги позволяют осуществить продление срока службы и жизни структуры самолётов через границы определённые расчётными условиями структуры самолётов.
\end{abstract}

Ключевые слова: самолёт, конструкция самолёта, фюзеляж, коррозия, коррозионная усталость, испытания без разрушения, испытания жизненного цикла, оценка жизненного цикла. 